ҚРР ТӘУЕАСІЗАІГІНЕ 30 ЖЫА

ҒTAMP 16.01.07 https://doi.org/10.26577/EJPh.2021.v183.i3.ph18

\title{
Г.Н. Смағұлова
}

Әл-Фараби атындағы Қазақ ұлттық университеті, Қазақстан, Алматы қ. e-mail: smagulova.g@mail.ru

\section{ТӘУЕАСІЗАІК ТҰҒЫРЫ - МЕМАЕКЕТTІК ТІААІН ҚОАААНЫСЫ}

\begin{abstract}
Мақалада мемлекеттік тіл ретінде қазақ тілінің қолданыс аясын талдап, саралау арқылы тәуелсіздік алғаннан кейінгі тіл саясатының қазіргі жағдайы сөз етіледі. Ұлт тілінің қазақ қоғамында қызмет етуі қаншалықты деңгейле, қалыптасу сатысы қалай, сондай-ақ, болашақтағы жағдайы қалай жоспарланып отыр деген сауа^дар та^данады. Бүгінгі қоғам өмірінің коммуникациялық актісіндегі мемлекеттік тілдің жұмсалу ерекшелігіне жүйелі де принциптік түрде қолдау көрсетілмесе, қоғамның даму векторына сәйкес қазақ тілінің перспективалық дамуы күманды болады. Сондықтан қазіргі жағдайда халықпен тікелей араласатын алдымен жергілікті атқарушы органдардың салаларында қазақ тілінің қазіргі қолданыс аясы туралы айты^ды. Қазақстанда тіл мәселесінің оңтайлы шешілуі мектепке дейінгі мекемелер мен жалпы орта білім беретін мектептердегі және жоғары оқу орындарындағы білім беру жүйесіне де тікелей байланысты. Бұл ретте Қазақстан Республикасындағы қазақ тіліндегі мектептер мен балабақшалардың санының артуы қазақ тілінің қоғамдық белсенділігін арттырып, ел аумағында тілдік ортаның қалыптасуына өз әсерін тигізуі әр жылдардағы деректер бойынша статистикалық көрсеткіштермен салыстырылды. Қазақстан Республикасында тілдерді дамыту мен қолданудың 2011-2020 жылдарға арналған және тіл саясатын іске асырудың 2020 - 2025 жылдарға арналған мемлекеттік бағдарламаларындағы көрсетілген мақсат пен міндеттеріне назар аудары^ды. Мемлекеттік тілдің бір қыры салалық мамандарға арналған терминологиялық мексиканы қалыптастыру мен дамыту жолдары қарастырылды. Қазақстанда тұратын кіші этникалық топтардың тілдерінен бөлек, тіл саясаты тұрғысынан көптілділікке ие үш тілдің: қазақ, орыс және ағылшын тілдерінің ресми мәртебесі мен қоғамдық қызметіне талдау жасалынды.
\end{abstract}

Түйін сөздер: мемлекеттік ті^, ті^ саясаты, тіл қолданысы, кәсіби қазақ тілі, қостілділік.

$$
\begin{gathered}
\text { G.N. Smagulova } \\
\begin{array}{c}
\text { Al-Farabi Kazakh National University, Kazakshtan, Almaty, } \\
\text { e-mail: smagulova.g@mail.ru }
\end{array}
\end{gathered}
$$

\section{The use of state language is the principles of independence}

The article focuses on current status of the language policy after gaining independence by analyzing the Kazakh language use as a state language. The issues about functioning level of the national language and its stage formation, as well as its future planning status in Kazakh society are discussed. Should there is no systematic and principal support for peculiarities of the state language applicability in the communicative act of present society, long-term development of the Kazakh language under the development vector of society is challenged. Therefore, initially, the current scope of the Kazakh language with respect to local executive bodies communicating directly with population at present has been discussed. The optimal solution to the language problem in Kazakhstan also depends on education system in preschools, secondary schools and universities. From this perspective, growing number of Kazakh-language schools and kindergartens in the Republic of Kazakhstan enhances social activity of the Kazakh language, and the impact on language environment formation in the country is compared to statistics of different years. The goals and objectives set out in the state programs of languages development and their use in the Republic of Kazakhstan for 2011-2020 and language implementation policy for 2020-2025 are reviewed. Consideration is given to one aspect of the state language - formation and development of terminological vocabulary for industry professionals. Apart from the languages of ethnic 
minorities living in Kazakhstan, official status and public function of three languages - Kazakh, Russian and English that are multilingual in terms of language policy are analyzed.

Key words: State language, language policy, language use, professional Kazakh language, bilingualism.

\title{
Г.Н. Смағұлова
}

Казахский национальный университет имени аль-Фараби, Казахстан, г. А^маты, e-mail: smagulova.g@mail.ru

\section{Использование государственного языка - принципы независимости}

\begin{abstract}
В статье рассматривается текущее состояние языковой политики после обретения независимости путем анализа использования казахского языка как государственного. Обсуждаются вопросы об уровне функционирования национального языка и стадии его становления, а также о будущем планируемом статусе в казахстанском обществе. В статье рассматривается Аолгосрочное развитие казахского языка в соответствии с вектором развития общества при отсутствии систематической и принципиальной подАержки особенностей применимости государственного языка в коммуникативном акте современного общества. Поэтому изначально обсуждалась актуальность казахского языка применительно к местным исполнительным органам, напрямую общающимся с населением.

Оптимальное решение языковой проблемы в Казахстане также зависит от системы образования в дошкольных учреждениях, средних школах и университетах. С этой точки зрения рост количества казахскоязычных школ и детских садов в Республике Казахстан повышает социальную активность казахского языка, а влияние его на формирование языковой среды в стране сравнивается со статистикой разных мет.

Рассмотрены цели и задачи, поставленные в государственных программах развития языков и их использования в Республике Казахстан на 2011-2020 годы и Политике внедрения языков на 2020-2025 годы. Также обсуждается один аспект государственного языка - формирование и развитие терминологической мексики профессиональной отрасли. Помимо языков этнических меньшинств, проживающих в Казахстане, анализируется официальный статус и общественная функция трех языков - казахского, русского и английского, которые являются многоязычными с точки зрения языковой политики.
\end{abstract}

Кмючевые слова: государственный язык, языковая политика, использование языка, профессиональный казахский язык, билингвизм.

\section{Kipicпе}

Қазақстан тәуелсіздік алғаннан кейін «Тіл туралы» заң қабылданғаннан бері қаншама толықтырулар, өзгертулер болды, тіпті жаңа заң қайта қабылдануы да мүмкін. Себебі қазақ тілі мемлекеттік тіл болғандықтан, бұл - заман мен қоғам талабы.

Ал қазақ тілінің қолданыс аясы ұлт тіліне қатысты қоғамдағы барлық проблемалардың ең өзекті тұсы екендігі даусыз.

МЕМЛЕКЕТТІК ТІЛ туралы әңгіме болғанда мына үш түрлі ерекшелікке назар аудару керек.

1 Мемлекеттік тіл (ағылшынша official, state language) дегеніміз - белгілі бір мемлекетте сәйкестіліктің, біртұтастықтың рәмізі, белгісі ретінде қабылданатын тіл.

2 Мемлекеттік тіл - белгілі бір мемлекеттің аумағында таралған, айрықша саяси-құқықтық заң дәрежесіндегі мәртебесі бар тіл.

3 Мемлекеттік тіл - нақты бір ел тұрғындарының ұлттық құрамына қарамастан мекеме- лер мен ұйымдарда, сот ісінде, құқық қорғау органдарында, білім беру мен денсаулық сақтауда, іс-қағаздарын жүргізуде қолданылатын міндетті тіл (Тіл блімі сөздігі, 1998).

Өткен тарихқа үңілсек, ұлттың тіл тіл саясаты мемлекеттік жүйеге түсу кезеңінен-ақ қалыптасқан заңдылық екеніне анық. Ұлт тілі қашанда өз халқы мен мемлекетіне, өз еліне, өз ұрпағына көп салада қызмет еткен тіл болғаны оның бүгінгі таңдағы түркі тілдерінің ішіндегі ең бай, ең құнарлы, әрі көркемдігін толық сақтағандығына дәлел болғаны еш күмансыз.

Бүгінгі тіл саясатында болашаққа барлау жасай отырып, қазіргі қоғам өмірінің коммуникациялық актісіндегі мемлекеттік тілдің жұмсалу ерекшелігіне жүйелі де принциптік түрде қолдау көрсетілмесе қоғамның даму ерешелігіне сәйкес қазақ тілінің ары қарай дамуы күман туғызады. Сондықтан, қазіргі жағдайда халықпен тікелей араласатын алдымен жергілікті атқ̧арушы органдардың жұмысы туралы айту керек. 
Жергілікті атқарушы органдардың қызметкерлерінің қазақ тілінде іс жүргізуі бірден нәтижелі бола қоймайды. Олардың қазақ тілінде iс жүргізу мүмкіндіктерін арттыру бағытында және көмек ретінде мемлекеттік тапсырыспен жыл сайын әртүрлі салалар бойынша орысшақазақша терминологиялық анықтамалық сөздіктердің, орысша-қазақша тілдескішердің, ресми ісқағаздары үлгілерінің жинақтары шығарылып, электронды нұсқасымен бірге кітап және диск түрінде таратылып отырады. Түйіндеп айтқанда, қазіргі танда:

- кеден ісінде

- денсаулық сақтау мкемелерінде

- санитарлық-эпидемиологиялық қызмет

- қаржы саласында

- елді жұмыспен қамту және әлеуметтік жағынан қорғау

- архттектура және құрылыс

- қоршаған ортаны қорғау

- логистика салаларында

- коммуналдық шаруашылық пен энергетика саласында

- сот ісі мен адвокатура және құқық

- жер қатынастары, тұрғын үй шарушылығы салалары бойынша ісқағаздарының үлгілері дайындалып, жинақтар ретінде сала қызметкерлеріне үлгі-әдістемелік құрал ретінде шығарылған. Жинақта қолданыстағы ісқағаздарының үлгілері қазақ және орыс тілдерінде берілген. Сәулет және құрылыс, білім беру және педагогика, ауыл шаруашылығы, төтенше жағдайлар, жер қатынастары және тағы басқа көптеген сала бойынша орысшақазақша тілдескіштер де жарық көрді. Осы шығарылған салалық сөздіктер тіл үйренуді жеңілдетіп, мемлекеттік тілде дайындалатын ісқағаздардың бір үлгіде болуын, мәтіндердегі бірізділіліктің сақталуына септігін тигізеді. Сала қызметкерлеріне арналған бұдан басқа 12 түрлі екі тілде анықтамалық терминологиялық сөздіктер жарық көрді. Аталған сөздіктерде тиісті салада жиі қолданылатын атаулардың, терминдердің, сөз тіркестерінің қазақ және орыс тілдеріндегі нұсқалары әліпби ойынша ғылыми түсініктермен берілген.

Дегенмен де аталған салаларда қазақ тілінің қолданыс аясы біршама қалыптасқан, мемлекеттік тілдің коммуникациялық функциялары айқындалып, ic жүзінде нәтижелі жетістіктер бар екендігі белгілі. Мәселен, ғылым тіліне қатысты жазылған терминологиялық зерттеу еңбектері мен сөздіктер, ресми ісқағаздар жүргізуге үлгіленген түрлі көмекші құралдар, оқулықтар т.б. толып жатқан игілікті іс шараларды айтуға болады.

\section{Зерттеу материалдары мен әдістері}

Еліміздегі тіл мәселесінің оңтайлы шешілуі мектепте дейінгі мекемелер мен жалпы орта білім беру ұйымдарын, жоғары оку орындарын да қамтиды.

Тілдің қолданыстық қызметінің негізі - оның жойылып кетпеу қаупіне, өмір сүру ұзақтығына тікелей әсер етеді. Адамның ана тілінде сөйлеуі мен тілді игеру қабілеті жас кезінен басталатындықтан тілдік саясатты осы кезеңмен байланыстыра қалыптастырған орынды. Дүниені тану, қоршаған орта туралы алғаш рет туған тілінде ақпарат беретін, балабақшалар мен мектептерде білім беретін, жоғары оқу орындары арқылы ана тілде тілдік сана мен тілдік ортаны өз дәрежесінде қалыптастыратыны түсінікті жайт.

Осыған орай, Қазақстан Республикасындағы қазақ тіліндегі мектептер мен балабақшалардың санының артуы қазақ тілінің қоғамдық белсенділігін арттырып, ел аумағында тілдік ортаның қалыптасуына өз әсерін тигізуі әр жылдардағы деректер бойынша статистикалық көрсеткіштермен салыстырылды.

Мәселен, Қазақстанда 2008 жылғы Республика бойынша балабақшалардың көрсеткіші:

Мектепке дейінгі тәрбие беретін балабақ̆шалар - 1617 $-703$

Қазақ тілінде тәрбие беретін балабақұшалар

Орыс тілінде тәрбие беретін балабақұмалар $-276$

Аралас тілде тәрбие беретін балабақцшалар $-664$

2011 жылғы Республика бойынша балабақшалардың көрсеткіші

Мектепке дейінгі тәрбие беретін балабақ-шалар - 2591

Қазақ тілінде тәрбие беретін балабақұшалар $-1401$ $-279$

Орыс тілінде тәрбие беретін балабақұшалар

Аралас тілде тәрбие беретін балабақұшалар - 858 https://adilet.zan.kz/kaz/docs/P100000488

Ал 2014 жылы Қазақстанда мектепке дейінгі мекеме 4972 болса, оның 2003 - балалар бақшасы.

2008-2009 оку жылындағы Республика бойынша мектептердің көрсеткіші

Барлық.мектептер-7620 Қазақ.мектептері $-3784$ 

$-2089$

Аралас мектептер - 1673 Oрыс мектептері

2011-2012 оқу жылындағы Республика бойынша мектептердің көрсеткіші

Барльқ мектептер - 7465

Қазақ мектептері - 3830

Аралас мектептер - 2090

Opыс мектептері - 1461

Еліміздің барлық аймақтарында қазақ тілінде білім мен тәрбие беретін мекемелер саны қаншалықты артқанынын статистикалық деректер әр түрлі ақпарат береді: 2012-2013 оку жылында республика мектептерінде білім беру бағдарламасы аясында, Қазақстанда жалпы білім беретін мектептердің 52\% - қазақ тілінде (3800 мектеп), 18,4\% - орыс тілінде (1345 мектеп), $28,5 \%$ - «аралас тілде» оқытатын (2088 мектеп), $1 \%$ - тәжік, ұйғыр, өзбек тілінде (3-тәжік тілінде, 14-ұйғыр тілінде, 57-өзбек тілінде) білім береді екен (Ы.Алтынсарин атындағы Ұлттық білім академиясы, 2015).

2014-2015 оқу жылының қарсаңындағы соңғы мәліметтерге қарағанда қазір Қазақстанда орта және жоғары оқу орындарының жанындағы мектептерді, арнайы түзету мектептерін қоспағанда:

\section{8 қазақ мектебі}

1442 орыс мектебі болды.

Сонымен қатар, 60 мектепте сабақ - өзбек тілінде, 13 мектепте - ұйғыр, 8 мектепте ағылшын, 2 мектепте - тәжік тілінде жүргізіледі. Оған қоса, 2161 мектепте сабақтар екі немесе одан көп тілдерде жүргізілді (Тіл саясаты, 2019)

Ал кейбір деректерде 3 тілде немесе одан да көп тілде оқытатын 90 (көптілді мектептер қатарында негізінен қазақ-түрік лицейлері), 11 Назарбаев зияткерлік мектебі мен мен дарынды балаларға арналған 33 арнайы мектеп білім беруін жалғастыруда (Президет-Халық, 2019).

Алайда кейінгі 2019 жылғы 31 желтоқсандағы № 1045 қаулысымен бекітілген Қазақстан Республикасындағы тіл саясатын іске асырудың 2020 - 2025 жылдарға арналған мемлекеттік бағдарламасындағы статистикалық деректерге назар аударсақ, қазақ мектептері санының төмендеу үрдісі байқалады:

«Қазақстанда 2018 жылғы мәлімет бойынша жалпы білім беретін 7393 мектеп бар, оның 3797-сі қазақ, 1312-сі орыс, 2255-і қазақ-орыс, 12-сі өзбек, 11-і ұйғыр, 1-еуі тәжік тілдерінде білім береді. Бұл мектептерде 2018-2019 оку жылында барлығы 3050770 оқушы білім алса, оның 2000000-нан астамы қазақша, 900000-ға жуығы орысша, қалғаны өзге тілдерде оқиды, яғни барлық оқушылар санының 66 \%-і қазақ тілінде білім алады.

Техникалық және кәсіптік білім беру саласында 2018-2019 оқу жылы қазақ тілінде білім алушылар саны 1991 жылмен салыстырғанда, 67 \%-ке артып, 289589 студентті құрады.

Егер 1998-1999 оқу жылдары жоғары оқу орындарында студенттердің жалпы санының 26,8\%-і қазақ тілінде білім алса, 2018-2019 жылдары 83\%-і қазақша білім алып отыр. Ағылшын тілінде оқытатын бөлімдері бар ЖОО саны да жыл өткен сайын артып келеді. Ағылшын тілінде білім алушылар саны 24,7 мың студентті құрады. Бұл 2009 жылғы көрсеткіштен 2,5 есеге артық (Тіл әлемі, 2021).

\section{Нәтиже және талқылау}

Орта білім беру салаларында мемлекеттік тілдің жан-жақты сапалы қолданылуы үшін аудио-электронды кітаптар баспадан шықты. Мысалы, «Балаларға базарлық», «Шәкірттерге шашу», «Асыл сөз», «Бізді қоршаған әлем» т.б. кітаптар білім алушылар тарапынан жоғары сұранысқа ие болды.

2011-2020 жылдарға арналған тілдерді дамыту мен қолданудың мемлекеттік бағдарламасы бойынша үлкен ауқымды жобаның аясында балаларға тіл үйрететін электронды оқу құралы «Сиқырлы қалам» интерактивті оқу-әдістемелік кешен жарық көрді. Бұл оқу құралының қазақ тілін үйретуде тәжірибелік маңызы зор.

Бұл көрсеткіштердің уақыт өте жылдам қарқынмен дамып келе жатуы болашақ ел азаматтарының қазақ тілін, яғни мемлекеттік тілді шынайы қоғамдық қызмет тіліне айналдыратындығына негіз болады.

Қоғамөмірініңбарлықсаласындатолыққанды қызмет атқару мәртебесіне ие мемлекеттік тілдің бір қыры салалық мамандарға арналған терминологиялық лексиканы қалыптастыру мен дамыту болып табылады.

Мәселен, қазіргі кездері хальққаральққ қыызметтегі мемлекеттік тіл қзолданысы жақсы нәтижелер беріп келеді. Дәстүрлі халықаралық терминдерді бұрын өзгеріссіз қолданатын. Соңғы кезде сыртқы қатынастар саласында бірқатар терминдер қайта қаралып, нақтыланды, шет мемлекеттердің атауы, халықаралық ұйымдардың, тіпті астаналары мен ірі қалаларының дұрыс жазылуына дейін (бұрын орыс тіліндегі нұсқасы аланатын) назар аударылды. Ал үш тілді (қазақша-орысша-ағылшынша және орысша-қазақша-ағылшынша), (француз- 
ша-орысша-қазақша), (немісше-орысша-қазақша)дипломатиялық сөздіктердің жарыққа шығуы халықаралық қызметте қазақ тілінің қолданылу аясын кеңейтуге, шетелдік дипломаттардың күнделікті жұмыстарына пайдалануға үнемі көмегі бар қажет сөздік болды (Дулатбеков, 1995; Оразалинов, Айымбетов, Бодаубай, Ақыпбекұлы, 2004). Қазақ тілінің халықаралық қатынастардағы орны мен рөлі дипломатия саласында мемлекеттік тілдің мәртебесін арттыру арқылы сапалық деңгейі өсті.

Барлық мемлекеттік органдарда осыған ұқсас министрлік қызметкерлері (қаржы, экономика және бюджеттік жоспарлау, ауылшаруашылығы т.б.) тіл біліктілігін көтеруге бағытталған көмекші құралдармен, әр түрлі сөздіктермен, оку әдістемелік кешенмен және электрондық әдебиет нұқаларымен қамтамасыз етілген.

Мемлекеттік қызмет саласындағы қазақ тілінің ахуалы сырттай қарағанда жақсы болып көрінеді. Себебі мекеме басшылары қазақ тілінде ісқағаздарын жүргізудің пайызы жоғары екендігін тілге тиек етеді Алайда мемлекеттік органдар қызметшілері көбінесе орыс тілділер екені бесенеден белгілі. Түрлі жиындарында оқылатын баяндамалар орысша дайындалып, орысша оқитындары әлі күнге дейін жалғасып келе жатыр.

Қай жерде болмасын терминология саласы ұдайы пікір талас тудырып отыратыны рас. Осы орайда бұл проблеманы жеңілдетудің бір тетігі жоғары оқу орындары студенттерінің өз мамандықтарына сәйкес «Кәсіби қазақ тілі» пәнін оқытудың да маңызы жоғары екендігі белгілі.

Мемлекеттік тілдің әлеуметтік-қатысымдық қызметін кеңейту мен дамытуда оның ғылымда, өндірісте, елдің халықаралық байланыстарында қолдану аясының кеңи түсуі тіл үйренушілердің болашақ мамандығымен байланысты екендігін көрсетеді. Тілді кәсіби дәрежеде меңгеру талабы бірінші кезекте болуы тиіс.

«Кәсіби қазақ тілін» оқыту бүгінгі күн талабындағы ғаламдану үрдісінде бәсекелестікке түсе алатын, мемлекетіміздің мақсаты мен мүддесіне қызмет ететін білікті маман даярлауда өзектілігі дау тудырмайды

Термин - арнаулы ғылыми ақпарат беретін тілдік бірлік ретінде номинация теориясында ғылыми ұғымдар атауларын құрайды. Сонымен қатар, қазіргі терминтанымда терминдерді тіркеу саласы мен олардың қызмет ету салалары ажыратылып жүр. Терминология үшін тіркеу саласы ретінде түрлі дереккөздер, мысалы сөздіктер, анықтамалықтар, энциклопедиялар т.б. болып табылады. Бұл салада термин статикалық күйде болып, мамандардың сөйлеу, қолданыс аясынан тыс қалпында көрініс береді. Дегенмен тіркеу саласы маңызды қызмет атқарады, себебі нақты коммуникация қажеттіліктерінен туындап, оның тиімділігін арттыру мақсатында терминологиялық лексиканы реттеу, біріздендіру, стандарттау жұмыстарын жүзеге асыруымен сипатталады.

Салалық терминдерді оқытып үйретудің негізі «Кәсіби қазақ тілін» оқытудан басталады. Терминдерді тіркеу саласында зерттеу парадигматикалық бағытта жүргізіледі. Яғни термин сөйлеу қолданысынан тыс болған жағдайда терминологиялық өріс бірліктерінің басқа парадигматикалық қатарлардағы, семантикалық топтардағы бірліктермен қарымқатынасы, оның өрістегі орны, семантикалық белгілері т.б. қарастырылады.

Ал терминнің қарым-қатынастағы қолданыстық қызметі түрлі ғылыми-техникалық мәтіндермен, кәсіби бағыттағы мәтіндермен, мамандар арасындағы тілдесіммен т.б. айқындалады. Терминдердің қолданыс саласы мамандардың кәсіби қызметінің үдерісінде жүзеге асып, бұл жағдайда терминдер түрлі құрылымдық т.б. өзгерістерге түсу нәтижесінде басқа терминдермен, сондай-ақ термин емес сөздермен де синтагматикалық байланыстарға ие болады.

Мамандардың кәсіби сөйлеуіндегі терминнің қолданыс саласы дегеніміз терминологиялық бірліктің ұғымдық көлемі мен дефинициясын толық қамтамасыз ететін орта болып саналады. Алайда мұндай жағдайға тек мамандардың сол терминологияның барлық ұғымдық қорын игеріп меңгерген жағдаятында ғана қол жеткізу мүмкін. Яғни терминдер мамандар саласында коммуникативтік қызметін атқаруы қажет.

Қазақ терминологиясын жүйелі зерттеп жүрген Ш. Құрманбайұлының еңбектерінде терминдердің коммуникативтік қызметіне қатысты пікірлері қай кезде болса да мазмұндылығымен құнды. «Әр ұлт өз тілінің өркендеуін, кең таралуын көздейді.Сол ұлттық тіл мемлекеттік тіл болып саналатын ел тіл саясатын өз жұртының тілдік мүддесін, оның бүгіні мен болашағын жан-жақты ойластыра отырып белгілейді» (Құрманбайұлы, 2014).

Мемлекеттік тілді оқыту барысында мамандыққа қатысты «Кәсіби қазақ тілі» қазір түйткілді мәселерді бастан кешіріп отыр. Бұл пәннің мақсаты мамандыққа кіріспе емес, қазақ 
тілін кәсіби деңгейде жетік меңгеру талаптарына негізделген.

Бұл пәнді аяқтаған тіл үйренуші:

- мемлекеттік тілде таратылатын мол ақпараттар толқынынан өзіне, өз мамандығына қажеттісін таңдап алып, оны коммуникативтіфункционалдық бағытта қолдана білуі керек;

- мемлекеттік тілде өзіндік көзқарасын таныта білу, оны дәлелдеп, қорғай білуі;

- өзінің алған білімі мен білік-дағдыларын, қазақ тіліндегі сөздік қорын, терминологияны үнемі дамытып отыруы;

- мемлекеттік тілде өз мамандығы аясында шешен сөйлеуге дағдылануы;

- кез келген жағдайда өз бетінше шешім қабылдай білуі;

- проблеманы танып, оны шешудің жолдарын айқындау, оны мемлекеттік тілде көркем жеткізе білуі керек және т.б.

Мемлекеттік тілдің әлеуметтік-қатысымдық қызметін кеңейту мен дамытуда оның қоғамның барлық саласында қолдану аясының кеңи түсуі тіл үйренушілердің болашақ мамандығымен байланысты екендігі баршамызға дау туғызбаса керек. Осыдан бәсекеге қабілетті, мемлекетіміздің мақсаты мен мүддесіне қызмет ететін білікті маман даярлауда бұл пәннің өзекті екендігі айқындалады.

Бұл ретте ғылыми теориялық және әдістемелік үдерістерді сараптай келе төмендегідей шешімдер іс жүзіне асырылып келеді:

- «Кәсіби қазақ тілі» пәні инновациялық технологияны кең қолдану мақсатында модульдық оқыту жүйесіне сәйкес жүргізіледі. «Кәсіби қазақ тілі» пәнін оқып меңгерудің алдында студент «Қазақ тілі» пәнін оқып үйреніп келеді. Тек тілді меңгергеннен кейін ғана модульдік оқыту жүйесі бойынша «Кәсіби қазақ тілін» оқып үйренеді. Осы тұрғыдан алғанда бұл пәнді жүргізу филолог мамандардың құзырына көшіп жатыр.

Коммуникативтік дағдыны қалыптастыру және дамыту, бәсекеге қабілетті әрі құзыреттілігі жоғары тұлғаның кәсіптік маңызы бар жағдайларда ғылым тілімен қазақша ойын толық және анық жеткізілуі - «Кәсіби қазақ тілі» пәнінің негізгі мақсаты болып табылады. Қазіргі таңда тілдік кәсіби бағдарды қамтамасыз еу үшін, бұл пәнді жоғары оқу орындарында қазақ тілі маманы жүргізіп жатыр.

Бұл ретте «Кәсіби қазақ тілі» пәні бойынша барлық мамандықтарға арналған бір типтік бағдарлама дайындалып, бекітіліп, қолданыста жүр.
Бұл бағытта жазылған «Кәсіби қазақ тілі» оқулықтары мен көмекші оқу құралдарының мазмұны мен құрылымының көпшілігіне ортақ тұстары:

- мамандықтарына сәйкес мәтіндер

- әр тақырыпқа қатысты терминдердің аудармасы мен сөздіктер лексикалық минимумдар

- қазақ тіліне тән дыбыстардың айтылуы

- грамматикалық категориялар

- сөз тіркестері мен сөйлемдер

қамтылып, сол арқылы тіл үйрену тәсілдері көрсетілген. Ал математика, физика, химия, информатика, география, биология, тарих, медицина, психология, салаларына байланысты жазылған «Кәсіби қазақ тілі» оқулықтары қолданыста әлі аз (Әбдиева, 2001).

Қай қоғамды алсаңыз да мемлекеттік тілі бар ұлт - ұлт, мемлекеттік тілі бар ұрпақ - болашағы бар халық. Бұл тұжырымды ешкім ешқашан өзгерте алмайды. Жылдар бойы адамзат тарихынан келе жатқан «тіл үшін күрестің» бар екендігі тілдің жай ғана қарым-қатынас құралы еместігін аңғартады. Бірақ, ең басты мәселе - ұлттың асыл қазынасы туған тілін сақтап қалу үдерісінде ұлт бірлігі, ел тұтастығы қашанда басты орында тұратындығы.

Қазақстан көп ұлтты мемлекет болғандықтан, түрлі диаспоралардың өзара мәдениарлық қатысымының маңызы зор. Бұл ретте барлығына қажетті «өркениетке қадам басқан адамзат өзінің қажетті игіліктері үшін бір-бірінен мәдениаралық қарым-қатынасты дамыту үшін өзге мәдениет пен тілді үйрену қажеттілігі туралы тұжырым жасаған америкалық антрополог зерттеуші Э. Холл «мәдениеттің қарым-қатынас үдерісімен бірігуі» деген аксиомалық қағидасымен назар аудартады (Hall, 1959: 5).

Қазіргі таңда мемлекеттік тіліміздің өз мәртебесіне сай қолданылу ерекшеліктеріне байланысты қоғамдық көптеген қарама-қайшы пікірлердің орын алып отырғаны баршамызға аян. Осы мәселеге байланысты түрлі даудамайлардың да туындап, әлі күнге өз шешіміне келмегені де жасырын емес.

Сонымен қатар, бүгінде Қазақстандағы тілдік саясат пен тілдік жоспарлаудың даму жағдайы құазақ-орыс қостілділігіне бағыт алып, Қазақстан республикасының Конституциясы мен Тіл туралы заңында қазақ тіліне - мемлекеттік тіл, орыс тіліне - ұлтаралық қарым-қатынас тілі мәртебесі бекітілгенді туралы тоқталуымызға болады.

Осыған орай:

- білім беру мен ғылым салаларындағы қазақ-орыс қостілділігі 
- өзге ұлт өкілдерінің ауызша формадағы қазақ-орыс қостілділігі

- түрлі ресми іс шаралар мен жиналыстарда, басқосуларда қазақ-орыс қостілділігінің белсенді қолданылуы

- жазбаша формадағы ісқағаздар мен түрлі қаржылық, экономикалық есеп-қисаптар, келісімшарттар және т.б. қазақ-орыс қостілділігі сияқты негізінен қазақ-орыс қостілділігінде жүзеге асырылуы бүгінгі Қазақстан республикасы тілдік саясатының шынайы тілдік ахуалын көрсетеді.

Енді елімізде жүргізіліп отырған тіл саясатының кейінгі жылдардағы ахуалына көз жүгіртсек, уақыт талабы мен дүниежүзілік өркениеттің сұранысына сәйкес көптілділіктің (үш тұғырлы тіл) де коммуникативтік сипаты белсенділікке ие болып келеді.

Бұған себеп: қазіргі жаһандану үдерісіндегі уақыт, кеңістік, контекст сынды этномәдени бірліктің талабы бойынша коммуникативтік өлшем айқын болуы тиіс. Коммуникативтік өлшем көпкомпонентті өлшемдер ішінде Г. Хофстеде «уақытқа қатынас және ұжымға деген қарым-қатынас» деген өлшемді бөліп көрсетеді (Hofstede, 1997). Шын мәнінде ұжым тіл иесі, оған әлеуметтік және этикалық мәртебе берілген. Ал қандай қоғам болса да заман, уақыт талабын ескереді. Мәселен, қазір «үшінші мәдениет адамы» деген түсінік бар. Ғаламтор желісінде бұл түсінік иммигранттардың екінші ұрпақтарының мәдениетіне қатысты ұғым. Мәселен, Қазақстандағы өзге тілді, демек көптілді мәдениеттер қатысымның астарында түсіндіріледі. Қазақстан тәуелсіздік алғанға дейін де, кейін де көшіп келіп қоныстанғандардың дені қазақ тілін меңгермеген. Ал олардың Қазақстанда өсіп келе жатқан ұрпақтары үшінші мәдениет өкіліне жатады. Бұлардың басқалармен мәдениаралық қатысымды оңтайлы жасауы интермәдени кеңістікте үшінші мәдени өкілін қалыптастырады. Айтып отырған үшінші мәдениет өкілі деген проблема әлі толық зерттелмеген.

Бұл ретте үлгі ретінде дамыған елдердегі әлемдік тәжірибені зерделей отырып, көптілділіктің қоғамдағы даму бағыттары және оның қызметін сондай-ақ, бір-біріне тигізетін тиімді немесе кері әсерінің нақты көріністерін саралап, ұдай жүргізілетін статистикалық мәліметтер мен зерттеулер аясында қадағалап, талданса құп болар еді. Сондай-ақ, болашақта социологиялық және әлеуметтік-лингвистикалық зерттеу орталықтарын құрып, көптілділіктің нәтижесінің талданғаны жөн.
Мемлекет аумағындағы тілдік жағдаят пен тілдік ахуалдың нақты көрінісі түрлі кезеңдік мерзімге сәйкес қарастырылып тұруы тиіс, нәтижесіне сәйкес Үкімет тарапынан тиімді заңнамалық өзгерістердің енгізілуі де дұрыс болар еді.

Әлеуметтік-лингвистикалық негіздемесіне қарай Қазақстанда өмір сүретін этникалық қауымдастықтардың, мәселен, славян тектес халықтардың дені бір тілді - славян тектестер, қостілді - жергілікті қазақ ұлты, ал ұйғыр, неміс, өзбек, татар, башқұрт, дүнген, кәріс, шешен, қырғыз, күрд және басқа да аз санды ұлт өкілдері көптілді болуы тиіс.

Бірақ ҚР «Тіл туралы» заңында «Қазақстанда тұратын басқа да ұлт өкілдері яғни, кіші этникалық көптілдінің қолданылуына және оларды үйренуге жағдай жасалады», - деп көрсетіледі.

Енді Қазақстанда тұратын кіші этникалық топтардың тілдерінен бөлек, тіл саясаты тұрғысынан көптілділікке ие осы үш тілдің: қазақ, орыс және ағылшын тілдерінің ресми мәртебесі мен қоғамдық қызметіне назар аударайық.

Мемлекет басшысы Қ. Тоқаевтың Қазақстан халқына жолдауында: «Ата заң бойынша Қазақстанда бір ғана мемлекеттік тіл бар. Бұл - қазақ тілі. Орыс тілі ресми тіл мәртебесіне ие. Біздің заңнамаға сәйкес, оның қолданылуын шектеуге болмайды. Болашағын Отанымызбен байланыстыратын әрбір азамат қазақ тілін үйренуге ден қоюға тиіс» - деп атап көрсетті. (Тоқаев, 2021).

Қазақ тілі - қазақтар үшін ата-баба тарихымен бірге мәңгі жасап келді. Қазақ тілі ұлт тілі болғандықтан өзінің ішкі лингвоэтникалық болмыс-бітімімен, тілдік жүйедегі заңдылықтарымен ерекшеленіп, ғасырлар бойы атадан балаға (жас, жыныс, сенім, кәсіп, әлеуметтік жағдай айырмасына қарамай) мирас ретінде берілген. Сондай-ақ, қарым-қатынас құралы қызметін атқарып келе жатқан қазақ халқының өз ана тілі.

Қазақ тілі - Қазақстан Республикасының Конституциялық мәртебесі бойынша, Қазақстан халқын топтастырудың аса маңызды факторы болып табылатын мемлекеттік тілі.

Мемлекеттік тіл:

- белгілі бір мемлекет аумағында кең таралған,

- республика тұрғындарының ұлттық ерекшеліктеріне қарамастан, мекемелер мен ұйымдарда,

- сот ісінде, 
- құқық қорғау органдары мен қарулы күштерде

- медицина мен білім беру жүйесінде,

- баспасөзде,

- өнер мен мәдениет салалрында

- іс қағаздарын жүргізуде қоғам өмірінде айрықша саяси-құқықтық мәртебеге ие, сәйкестіліктің, біртұтастықтың нышаны ретінде қолданатын негізгі тіл.

Opblc miлi - титулды ұлт қазақтардың тарихи тілі емес, бірақ ресми мәртебесі бар мемлекеттік тілмен тең дәрежеде қолданылатын ресми тіл және Қазақстандағы статистикалық мәлімет бойынша ең көп диаспора орыс халқының ана тілі, сондай-ақ басқа ұлт өкілдерімен өзара қарымқатынас тілі. Орыс тілінің өміршеңдігі мен қоғамдық қажеттілігі Қазақстанда аса белсенді.

Орыс тілі құзақ тілімен қатар елімізде:

- білім беру мен денсаулық сақтауда,

- банк пен экономика жүйесіндегі кірісшығыс, есеп-қисап тілі,

- мемлекеттік және жеке компаниялардағы түрлі іс қағаздар тілі,

- жаратылыстану салалары бойынша басымдыққа ие ғылым тілі,

- БАҚ, Масмедиа

- ғаламтор мен электронды құралдарда белсенді тіл больп тұрваны өмір шындывыл.

Бүгінгі Қазақстандавы тіл саясатында авылишын тілі:

- жаһандану кезіндегі өркениет талаптарына жауап беретін жаңа ақпарат таратушы инженерлік-компьютерлік технологиялар тілі,

- бизнес мен экономика тілі,

- халықаралық қатынастар мен іскерлер тілі,

- белгілі бір әлеуметтік топтар үшін (жастар) жоғары еңбекақы мен тұрақты жұмыс орнын сақтап тұруға мүмкіндігі бар заманауи тіл болып тұр.

Болашаққа үлкен бетбұрыс ретінде Қазақстандағы тіл саясаты қоғамдық-саяси, экономикалық, өркениеттік, электронды-ақпараттық, жаһандық сұраныстар мен қажеттіліктерге сәйкес «қазақ-орыс-ағылшын» көптілділігін қалыптастыруды қолға алды.

Қазақстан Республикасындағы тіл саясатын іске асырудың 2020 - 2025 жылдарға арналған мемлекеттік бағдарламасының мақсатында: қазақ тілінің мемлекеттік тіл ретіндегі толыққанды қызметін қамтамасыз ете отырып, латын графикалы әліпби негізінде қазақ тілін жаңғыртуға, тіл мәдениетін одан әрі арттыруға және тілдік капиталды дамытуға бағытталған үйлесімді тіл саясатын жүргізу деп көрсеткен.
Бағдарлама бойынша, Мемлекеттік тілдің этносаралыққатынастіліретіндегірөлінкүшейту; Білім беру саласындағы қазақ тілінің функцияларын кеңейту және оны қолдану мәдениетін арттыру; Мемлекеттік және мемлекеттік емес сектор ұйымдарында қазақ тілін меңгеру деңгейін арттыру; Ақпараттандыру және коммуникация саласындағы қазақ тілінің қолданылуын жетілдіру; Мәдениет, халыққа қызмет көрсету, БАҚ және бизнес саласында мемлекеттік тілдің қолданылуын реттеу, әлеуметтік беделін арттыру; Халықаралық коммуникацияда қазақ тілінің қолданылуын кеңейту т.б; (Бағдарлама, 2020).

Қазақ тілі - мемлекеттік тіл. Ал мұндай шетін мәселеге назар аудармаған БАҚ - бұқаралық ақпарат құралдары жоқ. Осылардың ішінде интернет ресурстарында ғана мемлекеттік тілге арналған жарияланымдарға үн қатқан қалың бұқара ашық пікірлерінің өзі талдауды қажет ететін бір салаға айналып отыр. Көпшілік қолданатын ғаламторда да тіл туралы мәселе қозғалып жатқаны қуантарлық жәйт. Әрине, тіл мәселесі интернетте де оң шешімін тауып жатса, қолданыс аясындағы күрмеуі көп қазақ тілінің бір түйіні шешілер ме еді...

Қазақ тілінің мемлекеттік мәртебесі туралы интернет сайттарында өз пікірін жарияламаған қазақстандық кемде кем. Азаматтық көзқарасы ендіқалыптасыпкележатқанмектепоқушысынан бастап озық ойлы қоғам қайраткерлері де өз тұжырымын, ішкі ойын қалдырғанын көресіз.

«Мемлекеттік тіл» туралы заң жобасының баптарына қатысты Интернет желісіндегі талқылауларға да назар аудару керек. Себебі кейбір интернет желілерінде мемлекеттік тіл мәселесі «ура-патриоттық» жалған тек сөз жүзінде ғана талқыланып жатқан сыңай бар. Қазіргі жағдайда кез келген ортада тілге құрмет алдымен қазақтардың өзі қарапайым үй-ішілік, тұрмыстық жағдайдан бастап, әр жердегі icәрекетінде қазақша сөйлеп жүрсе құба-құп болар еді. Ғаламтор желісіндегі тіл жанашырларынын ащы болса да, оңды пікірлеріне құлақ асу керек.

Қазақ тілінің қолданыс аясына қарай жүргізілген сауалнама нәтижелерін де айта кетсек. (*Ocы мақуала авторының мемлекеттік грант аясында жүргізген «Қазақ тілінің даму тенденциясы» Жоба материалдарынан альHbin omblp.) Сауалнаманы халық арсында кез келген әлеуметтік топқа жүргізілетін нағыз демократиялық бақылау деуге болады. Бұл ретте мемлекеттік тілдің қолданыс аясын білу үшін ғылыми зерттеу мақсатындағы сауалнамаға тек орыс тілділер таңдалды. Сауалнама 1000 
адамға жүргізілді. Жүргізілген сауалнаманың нәтижелерін көрсек.

Мемлекеттік тілді дұрыс білмегендіктен туатынқиындықтарғасауалнамағақатысушылардың басым бөлігі тек құана ісқаваздар жүргізу ісінде ғана тап болатынын айтты. Ал қазіргі жағдайдағы ісқағаздар ісін жүргізу бойынша оқулықтардың, оқыту-әдістемелік құралдардың, әдебиеттің жеткіліктілігіне қарамастан, сауалнама қатысушылары әлі де оқыту-ддістемелік құралдардың аздығынан деп есептейді. Бірақ көптеген адамдар қазақ тілін үйрететін оқулықтар негізінде өз бетімен-ақ тілді меңгеріп алған жағдайлар да жеткілікті екені рас.

Сонымен қатар, сауалнамаға қатысушылар Отан алдындағы азаматтық борыш, патриоттық емес, тек Қазақстанда өмір сүру ниеті, не болмаса мансапқ̧а қ̧ол жеткізу ниеті ғана мемлекеттік тілді үйренудегі негізгі стимул болып отырғанын байқатты.

\section{Қорытынды}

Жоғарыда талданған мәселелрді қорыта келгенде, қазақ тілінің қоғамдық қызметі қоғамдық өмірдің аса маңызды мынадай салаларында жүзеге аса бермекші:

- кезкелген басқару органдары, ақпарат, білім беру мен тәрбие ісі, ғылым мен техника салаларында;

- Қазақстан ғылымының дамуы сатысында: қоғамдық ғылымдар, жаратылыстану мен нақты ғылымдар, техникалық және қолданбалы ғылым, экономика салаларында, ғылымның жалпыға ортақ салаларында және БАҚ, ісжүргізу саласында;

- Мемлекетке тиісті: қоғамдық-саяси, мәдени мекемелер мен ұйымдарда;

- Түрлі министрліктерге қатысты ұйымдар: дене тәрбиесі, спорт, туризм, денсаулық сақ- тау мен емдеу мекемелерінде; қоғамдық тамақтандыру орындарында;

- Халыққа қызмет ететін өнер мекемелерінде (театр, кино);

- Халықаралық дипломатиялық қарымқатынаста;

- Коммерциялық емес Акционерлік қоғамдағы шаруашылық жүргізу және ұйымдастыруда;

- Мемлекет аумағындағы өндіріс және өнеркәсіп орындарында;

- Қазақстан Республикасында өтетін республикалық, халықаралық құрылтай, конференция, мәжіліс, жиындар т.б.

Санамалап көрсетілген бұл баптарда үлкен жауапкершілік жүктейтін міндеттер көрсетілген. Қазақстанның әр азаматы мемлекеттік тіл саясатын жоспарлы түрде асыру бағытында ұлтының, келер ұрпақтарының болашағы үшін сын кезеңде жүргенін есте ұстағаны абзал. Мұндай биік мақсаттардың ең басында тұрған мәселе - әр қазақстандықтың қазақ тіліне деген жауапкершілігін барынша жан-жақты сезінуі. Мемлекеттік тіл қарым-қатынас тілі болумен қатар, Қазақстан мемлекетін әрі қарай дамытушы әрі сақтаушы фактор ретінде ұғынылуы тиіс. Қазіргі кезде қазақ тілінің бай сөздік қоры, тілдің поэтикалық қуаты, оның жан-жақты қолданыс мүмкіндіктері тілді тұтынушының кез келген сұранысын толық қанағаттандырады.

Ақпараттық-технологиялық ғасырда қазақ тілінің өрісі кеңейіп, басқа да тілдердей нығайып, орныға түсуі үшін қазақ тілін әр маман кәсіби дәрежеде меңгеруі керек. Мемлекеттің тілдің қолданыс аясын одан әрі жан-жақты кеңейтуге әрбір қазақстандық азамат мүдделі болуға тиіс. Елбасының «Қазақ қазақпен қазақша сөйлессін» деген дегені Мемлекеттік тіл иелерінің қай кезде болса да жадында жаңғырып тұруы керек! (Назарбаев, 2010)

\section{Әдебиеттер}

Словарь по языкознанию. Тіл білімі сөздігі. - Алматы: «Ғылым», 1998. - 540 б.

Қазақстандағы орта білім: жағдайы және болашағы. Талдамалық жинақ. - Ы.Алтынсарин атындағы Ұлттық білім академиясы. - Астана, 2015. - 224 б.

https://mtdi.kz > til_sayasaty [Электр.pecypc]

https://pr-hal.kz/aleumet/aza-standa-y-mektepter-a-yz-ben-a-i-at/ [Электр.pecypc]

https://www.tilalemi.kz > new [Электр.peсурс]

Сөздіктер:

Заң терминдерінің қазақша-орысша және орысша-қазақша сөздігі / Құраст. Н.О. Дулатбеков және т.б. - Алматы: Жеті жарғы, 1995. - 144 б. 
Заң терминдерінің сөздігі. - Словарь терминов законадательства / Құраст.: Оразалинов С., Айымбетов М., Бодаубай Б., Ақыпбекұлы Ө. - Алматы: Жеті жарғы, 2004. - 656 б.

Дипломатиялық сөздік. Қазақша-орысша-ағылшынша және орысша-қазақша-ағылшынша. -Астана, 2010.

Бакитов А., Жуманова Р. Французша-орысша-қазақша, қазақша-орысша-французша дипломатиялық терминдер сөздігі. - Алматы: ЖШС «Фирма Орнак», 2013. - 380 б.

Шалгинбаева Р. Немісше-орысша-қазақша, қазақша-орысша-немісше дипломатиялық терминдер сөздігі. - Алматы: «Фирма Орнак», 2013. - 396 б.

Құрманбайұлы Ш. Қазақ терминологиясы. - Алматы: Сардар, 2014. - 9026.

Кәсіби қазақ тілі:

Әбдиева Ш.Д. Қазақ тілі. Прокурорлық-тергеу факультетінің студенттеріне арналған оқу құралы (Бастауыш және орта топ студенттеріне арналған). - Алматы: ҚазМЗА, 2001. - 135 б.

Қожабеков Е., Төлеутай. «Құқық қорғау органдары қызметкерлеріне арналған әдістемелік оқулық». - Астана: «Әлеуметтік лингвистика орталығы» ЖШС, 2010. - 157 б.

Күзекова 3., Құрманбайұлы Ш., Жусанбаева С., «Қазақ тілі халықаралық қатынастар мамандығына» арналған оқу құралы. - Алматы: Ана тілі, 1998. - 205 б.

Ақбұзауова А. «Кәсіби қазақ тілі» әскери сала бойынша. - Алматы: Ана тілі, 1998. - 198 б.

Қарабаева Қ. «Қазақ тілі» (әскери сала бойынша). - Алматы, 2008. - 304 б.

Жұмағұлова А.Ж. Кәсіби қазақ тілі: оқу құралы. - Алматы: Қазақ университеті, 2011. - 227 б.

Ақбұзауова Б. Кәсіби қазақ тілі: оқу құралы. - Алматы: Қазақ университеті, 2011. - 177 б.

Hall E (1959) The Silent Language. - Garden City, N.Y.: Anchor Press / Doubleday. - 240 p.

Hofstede G (1997) Cultures and Organizations: Software of the Mind. - N.Y..: McGrow-Hill. - 279 p.

Қ. Тоқаевтың Қазақстан халқына жолдауы. https://www.primeminister.kz > address [Электр.pecypc]

Қазақстан Республикасындағы тіл саясатын іске асырудың 2020 - 2025 жылдарға арналған мемлекеттік бағдарламасы https://egemen.kz > last-news [Электр.pecypc]

Н.Ә. Назарбаевтың Қазақстан халқы Ассамблеясының XVI сессиясында сөйлеген сөзі http://www.egemen. kz/2010/10/21/18867 [Электр.ресурс]

\section{References}

Ábdıeva Sh.D (2001) Qazaq tili. Prokýrorlyq-tergeý fakúltetiniń stýdentterine arnalǵan oqý quraly (Bastaýysh jáne orta top stýdentterine arnalǵan). [Kazakh language. Textbook for students of the prosecutor's and investigative faculty (for students of Primary and secondary groups)]. Almaty: Kazmza, 135 p. ), (In Kazakh)

Qojabekov E., Tóleýta1 (2010) Quqyq qorǵaý organdary qyzmetkerlerine arnalǵan ádistemelik oqýlyq [methodological textbook for law enforcement officers]. Astana: Center for social linguistics LLP, 157 p. (In Kazakh)

Kúzekova Z., Qurmanba1uly Sh., Jýsanbaeva S (1998) Qazaq tili halyqaralyq qatynastar mamandyǵyna arnalǵan oqý quraly [Kazakh language in the specialty of international relations]. - Almaty: native language, 205 p. (In Kazakh)

Aqbuzaýova A (1998) Kásibı qazaq tili áskerı sala boiynsha [professional Kazakh language in the military field]. Almaty: native language, 198 p. (In Kazakh)

Qarabaeva Q (2008) Qazaq tili (áskerı sala boınsha) [Kazakh language (in the military field)]. Almaty, 304 p. (In Kazakh)

Jumaǵulova A (2011) Kásibı qazaq tili: oqý quraly [professional Kazakh language: a textbook]. Almaty, Kazakh university, 227 p. (In Kazakh)

Aqbuzaýova B (2011) Kásibı qazaq tili: oqý quraly [professional Kazakh language: a textbook. - Almaty: Kazakh university, 177 p. (In Kazakh)

Qazaqstandaǵy orta bilim: jaǵdaıy jáne bolashaǵy (2015) [Secondary education in Kazakhstan: state and prospects. Analytical collection]. National Academy of Education named after I. Altynsarin. - Astana, 224 p. (In Kazakh)

Qurmanbaiuly Sh (2014) Qazaq termınologiasy [Kazakh terminology]. Almaty: Sardar, 902 p.

Q.Toqaevtyń Qazaqstan halqyna joldaýy. [Address of K. Tokayev to the people of Kazakhstan] https://www.primeminister.kz > address [electric.resource] (In Kazakh)

Qazaqstan Respýblıkasyndaǵy til saıasatyn iske asyrýdyń 2020 - 2025 jyldarǵa arnalǵan memlekettik baǵdarlamasy [State program for the implementation of language policy in the Republic of Kazakhstan for 2020-2025] https://egemen.kz > last-news [electric.resource] (In Kazakh)

N. Á. Nazarbaevtyń Qazaqstan halqy Asambleıasynyń XVİ sesıasynda sóılegen sózi [Speech of N. A. Nazarbayev at the XVI session of the assembly of people of Kazakhstan] http://www.egemen.kz/2010/10/21/18867 [electric.resource] (In Kazakh)

Hall E (1959) The Silent Language. - Garden City, N.Y.: Anchor Press / Doubleday. - 240 p.

Hofstede G (1997) Cultures and Organizations: Software of the Mind. - N.Y..: McGrow-Hill. - 279 p.

Sózdikter (1995, 2004, 2010, 2013)

Zań termınderiniń qazaqsha-oryssha jáne oryssha-qazaqsha sózdigi. Qurast.N.O.Dýlatbekov jáne t.b.[ Dictionaries: 1.KazakhRussian and Russian-Kazakh Dictionary of legal terms. Comp.N. O. Dulatbekov et al.] Almaty: Zheti zhargy, 144 p. (In Kazakh) 
Zań termınderiniń sózdigi. -Slovar termınov zakonadatelstva. [Dictionary of legal terms. Comp.: Orazalinov S., Aimbetov M., Bodaubay B., Akypbekuly U.] Almaty: Zheti zhargy, 2004. - 656 p. (In Kazakh)

Diplomatıalyq sózdik [diplomatic dictionary] Astana, 505 p. (In Kazakh)

Bakıtov A.,Jýmanova R. Fransýzsha-oryssha-qazaqsha, qazaqsha- oryssha- fransýzsha dıplomatıalyq termınder sózdigi [Bakitov A., Zhumanova R. Dictionary of French-Russian - Kazakh, Kazakh - Russian-French diplomatic terms]. Almaty: Firma Ornak LLP, 380 p. (In Kazakh)

Shalgınbaeva R.Nemisshe-oryssha-qazaqsha, qazaqsha-oryssha-nemisshe dıplomatıalyq termınder sózdigi [Shalginbaeva R. Dictionary of diplomatic terms in German-Russian-Kazakh, Kazakh-Russian-German] Almaty: Firma Ornak, 396 p. (In Kazakh)

Slovar po 1azykoznanı́. Til bilimi sózdigi (1998) [Dictionary of Linguistics. Dictionary of linguistics]. Almaty: Science, 540 p. https://mtdi.kz > til_sayasaty [Elektr.resýrs]

https://pr-hal.kz/aleumet/aza-standa-y-mektepter-a-yz-ben-a-i-at/ [Elektr.resýrs]

https://www.tilalemi.kz > new [Elektr.resýrs] 